UDC 342.9

DOI https://doi.org/10.32849/2663-5313/2021.11.09

Vitalii Oksin,

Doctor of Law, Leading Researcher, Scientific Institute of Public Law, 2a, H. Kirpy street, Kyiv, Ukraine, postal code 03035,6222410@ukr.net

ORCID: orcid.org/0000-0001-6080-7752

Oksin, Vitalii (2021). Administrative instruments for activities of public administration in local development in Ukraine. Entrepreneurship, Economy and Law, 11, 70-76, doi https://doi.org/10.32 849/2663-5313/2021.11.09

\title{
ADMINISTRATIVE INSTRUMENTS FOR ACTIVITIES OF PUBLIC ADMINISTRATION IN LOCAL DEVELOPMENT IN UKRAINE
}

Abstract. The purpose of the article is to establish administrative instruments for the activities of public administration in local development in Ukraine.

Results. The article studies legal regulations and theoretical developments concerning the concept and elements of administrative instruments of the activities of public administration in local development in Ukraine. It is established that the administrative instruments of the activities of public administration in local development can be classic forms of administrative activity and specific methods of their implementation. The author argues that the main instrument for public administration of local development in Ukraine is an administrative provision, or more precisely, their totality in a specific regulation, the most recent of which is represented by the legal regulatory framework that logically integrates all the principles, rules and procedures that are essential for the efficiency and effectiveness of a particular public administration. The study concludes that the instrument of implementation of public administration of local development in Ukraine and the instruments of activities of public administration implementing the mechanism for state power and service implementation of public authority in local communities are different legal phenomena, while the instruments of its implementation are concrete administrative actions of authorized public administrators of local development.

Conclusions. Therefore, the administrative instruments for the activities of public administration in local development in Ukraine are the interrelated set of external expressions of the activities of the public administrators (forms) and the ways of their influence on legal relations (methods) in respect of local development administration, which contribute to the implementation of specific actions, goals and strategies for local development, settlement of local issues, and meeting the legitimate needs of society in the democratization process.

Key words: administrative legal instruments, local development, public administration, activities, forms, methods, administrative provision.

\section{Introduction}

The processes of political transformation in the State, the establishment of a new State structure and a new system of local selfgovernment have required new views on the already existing forms and methods of public administration of local development in Ukraine. Although the legal science pays sufficient attention to the study of the fundamental principles of the functioning of local development, the issues of organizational legal forms and methods of work of public administration on local development in Ukraine remain largely neglected by scientists, despite the increasing scope of issues being solved by the local authority (Shpak, 2013, pp. 58-62).

The development of regional selfgovernment, impact of decentralization on the development of the State and territorial communities, improvement of the organizational and methodological principles of administration of local and regional development and some related public administration issues have been studied by scientists such as: V. Averianov, M. Azhazha, O. Altunina, A. Artemenko, O. Batanov, I. Bezena, Yu. Bytiak, K. Blishchuk, O. Bobrovska, I. Bovsunivska, H. Vasylchenko, Yu. Vorobiov, P. Vorona, V. Voronkova, O. Yevsiukova, N. Yeremenko, Ya. Zhovnirchyk, O. Zahorodnyuk, O. Zamrii, O. Zvizdai, A. Zienina-Bilichenko, P. Klymenko, M. Kovalenko, M. Kovaliv, A. Kozhyna, K. Kolesnykova, N. Kolisnichenko, N. Komar, I. Kostenok, V. Kostytskyi, V. Kruhlov, S. Maistro, Yu. Napalkina, D. Nekhaichuk, O. Nyzhnyk, O. Remeniak, S. Rudeichuk, 
L. Sameliuk, O. Svitovyi, I. Semyhulina, S. Serohin, M. Sydor, and others. However, from the perspective under concern, the issue has not been addressed in their scientific research.

The purpose of the article is to establish administrative instruments for the activities of public administration in local development in Ukraine.

\section{Particularities of public administration}

Generally, the instruments of the activity of public administration in local development in Ukraine are a set of ways of exercising their competence. However, literature review reveals a lack of unified, well-established scientific approaches to the issue of administrative instruments of public administration activities in the field of local development in Ukraine (Shpak, 2013, pp. 58-62).

In particular, contemporary academic standpoints state that public administration instruments include the forms and methods of administrative activities of public administration (Halunko et al., 2018, p. 143). Thus, some scientific perspectives should be analysed to formulate the essence of the forms of activities. For example, Yu. Starilov defines forms of administration as externally expressed and legally formalized actions of an administration body (or an official) within its competence and with legal effects defined by law (Starilov, 2002). The scientist argues that the forms of public administration are characterised as follows: they are set out in a legal regulation; they are of a State-power nature; they are subsidiary due to the by-law nature of the powers of administration and its officials; the forms of public administration are executive and administrative. According to the scientist, the forms of public administration are used by the executive authorities, that is, the administrative bodies of public authority. Specific forms of public administration include the issuance of legal regulations, non-legislative (individual) legal regulations, conclusion of contracts, other legally significant acts on the basis of a law or on the basis of an issued administrative legal regulation, organizational actions, logistical actions (Starilov, 2002, p. 212).

According to V. Bila, the legal form of public administration is an objectivation, structured in accordance with the established legal procedure, in the administrative law of the expression of the will of the authorized person to perform functions of public administration of the subject, which gives rise to legal effects in substantive and procedural matters. The above-mentioned effects arise in accordance with the scope, legal force and legal content of the power dictates defined by the competence of the person expressing the will and by the stage of the administrative-legal regulatory mechanism (Bila, 2020, p. 4).

Referring directly to the concept of "instruments of administrative activity", I. Paterylo comprehensively determines that the replacement of the category of "forms of State administration" with the concept of "instruments of activities of public administration" is now necessary and timely; these are the totality of means used by public administrators to regulate public relations arising in public administration (Paterylo, 2013, p. 289).

More systematically, V. Halunko defines the instrument of public administration as an external expression of the homogeneous in its legal nature groups of administrative actions by public administrators, carried out in strict compliance with the competence defined by law, with a view to achieving the result required for public administration (Halunko et al., 2018, p. 143).

Moreover, from our perspective, the main instrument for public administration of the local development in Ukraine is an administrative provision, or more precisely, their totality in a specific regulation, the most recent of which is represented by the legal regulatory framework that logically integrates all the principles, rules and procedures that are essential for the efficiency and effectiveness of a particular public administration.

We are convinced that the instrument of implementation of public administration of local development in Ukraine and the instruments of activities of public administration implementing the mechanism for State power and service implementation of public authority in local communities, are different legal phenomena. For example, one of the instruments of public administration of local development in Ukraine is the State Strategy for Regional Development (currently approved for 2021-2027 by the Resolution 695 of the Cabinet of Ministers of 5 August 2020), while the instruments of its implementation are concrete administrative actions (forms and methods) of authorized public administrators of local development.

Nevertheless, in the administrative law study, forms of public administration are forms of administrative activity of public administration grouped into: issuance of administrative regulations (issuing by-laws and individual administrative regulations); concluding administrative agreements; performing other legally significant administrative actions; logistical operations (Halunko et al., 2018, p. 143). 
In fact, the issuance of individual administrative regulations is the most common way of exercising administrative powers by public administration bodies; without their issuance, no more or less important case in this field can be resolved. The issuance of individual administrative regulations is close to the regulatory, but not identical. The difference is that individual administrative regulations establish, modify or terminate specific administrative legal relations. In contrast with regulatory ones, they address specific actors in administrative relations and are terminated after the exercise of the rights and obligations established therein (Halunko et al., 2018, p. 135).

V. Bila studies the category of individual regulation of public administration and highlights the following main features:

1) it is the expression of the will of the public administrator to exercise own competence in respect of a specific situation, the person, the property, the object of the material world and the legal regime. In contrast with a legal regulation, an individual regulation of public administration is not always a decision and is not always of a managerial nature;

2 ) it is powerful, that is, binding, supported by legal means, including the possibility to use administrative coercive measures and legal liability;

3) it has special legal effects, such as the ability to bring about changes in the administrative and legal status of a person, the legal regime of property, the object, the territory and the situation. The difference between a legal regulation and an individual regulation of public administration is not only in the legal content, the functions performed and the modifications of the legal effects, but also in the scope of the latter. While a legal regulation of public administration may directly change the provisions of other branches of law, an individual regulation of public administration always causes changes in the administrative and legal status of a person, so indirectly influences one's ability to exercise rights and perform duties in other legal relations;

4) it expresses the state of the art in the functions of public administration, as it is exhausted by the execution of the prescriptions therein (Bila, 2020, p. 284).

The adoption of regulations by bodies and officials of local self-government is a legal form of the exercise of their own powers and powers delegated by the State. Legal regulations of local self-government differ in form, content, legal force, legal properties, action in time and space, procedure and grounds for adoption. The purpose of the classification is to identify the specificities of the groups of the regulations in question, which is important in their issuance. A proper classification orders a rather complex and comprehensive system of legal regulations of local self-government, enables to identify objective trends and patterns in the development of this system and to better understand the legal nature of these regulations, to establish clear control over their implementation, ensures a proper scientific approach in the systematization of these regulations, that is, contributes to the improvement of the legal forms of activity of bodies (officials) of local self-government (Kalynovska, 2009, pp. 219-224; Kovalenko, 1997, p. 3).

Individual regulations include the municipal legal regulation as a temporary official legal instrument adopted by the territorial community, a body or an official of local selfgovernment within their own or delegated powers, in the manner and form prescribed by the Constitution, thelaws of Ukraine, the Statute of the territorial community and the regulations of the Local Council, aimed at establishing, amending, supplementing (revising) or cancelling legally binding regulations intended for repeated application in the territory concerned. The system of municipal legal regulations is a complex and comprehensive set which, in terms of scope and composition, does not coincide with the general system of sources of Ukrainian law. The two systems overlap. The intersection point is the municipal legal regulations and regulations adopted within the scope of delegated powers, combined with the form of law such as legal regulations as well as regulatory contracts. The rules of conduct in the legal regulations of local self-government, although not originating from the State, but of State power character, since they exercise municipal power. The latter is an expression of the people's power, one of the foundations of the constitutional order of Ukraine. Therefore, in the provisions of local selfgovernment regulations there is not only "power of authority" of local self-government, but also the authority, power of municipal authority as special public authority under the unified system of people's power (Petryshyna, 2012).

Therefore, the issuance of individual administrative regulations as a form of administrative activity of a public administrator of local development is law application of specific individual prescriptions of a public administrator, the legal content thereof is the creation, modification and termination of internal administrative legal relations, temporary or definite.

The collective issuance of regulatory and individual administrative regulations by 
the public administrators of local development is the exercise of the will of the public administrator during his or her term of office of a general or specific individual nature, which define specific local development activities, goals and plans related to finance, infrastructure development, involvement of entrepreneurs, investors, business projects, improvement of the quality of services at the local level, addressing other local issues and different needs of the territorial community.

With regard to administrative contracts, an administrative contract is a public agreement between two or more subjects of administrative law, one of which is always a public administrator. The features of an administrative contract are: 1) subjectivity - mandatory participation of the public administrator; 2) a subject matter - its content is the rights and obligations of the parties arising from the managerial functions of the public administrator (Halunko et al., 2018, p. 137).

3. Particularities of relations of public administration

Public administration bodies always enter into contractual relations for the purpose of realizing a public interest, while the delimitation of administrative and economic contracts are the effects of performing the obligations assumed by the unauthorised entity. If such effects achieve a socially significant result, the contract is an administrative one if the effect of the contract is to meet economic needs of public administration body and to generate profits for the economic entity, it is economic (Bila, 2020, pp. 264-265).

Thus, administrative contracts are a rather common form of administrative activity of public administrators of local development in Ukraine, which is concluded between two administrative actors in different forms (agreement, memorandum, protocol) and contain powers in respect of joint legal measures of activity, partnership, solution of obligations in the public-legal field of local development.

The next legal form is organizational actions. These include various activities aimed at improving the work of public administration personnel, advancing the organization of work and executive discipline, and implementing good practices and state-of-the-art technologies. At the same time, they can be used to influence social structures and citizens. These actions have no direct legal effect. Such actions may include various instructions, meetings, seminars, meetings, conferences, practical assistance, dissemination of good practices, monitoring activities, and the study of public opinion, measures to introduce the latest achievements of science and technology (Kolpakov, 2012, pp. 102-103).

Since the actions constituting the content of the organizational form of the activity do not necessarily have to be enshrined in the law, the organizational and legal form of the activity is often identified in the legal literature. In particular, according to the Law of Ukraine on Local Self-Government, the organizational legal forms of the activities of local selfgovernment bodies may be: sessions; separate and general meetings of the permanent commissions, sub-commissions and working groups; meeting of the presidium of the oblast, district councils; meeting of provisional monitoring committees; personal work of the Chairman of the Council, the Secretary, the Deputy Chairmen of the Council, the Executive Committee of the Council, the work of the deputies in the electoral districts, the participation of the Chairman of the Council or the deputies in the general meeting of citizens in their place of residence; participation of deputies with the right to advisory vote in meetings of other local councils and their bodies and self-organization bodies; reports of the rural, township and city head to the territorial community; and reports of deputies to the electorate (Verkhovna Rada of Ukraine, 1997; Kaminska, 2010, p. 101).

At the same time, the list of organizational forms of work of local self-government bodies cannot be exhaustive. Community life is so multifaceted that new organizational forms of local government are constantly being sought to improve their functioning, so the legal and regulatory consolidation of the list of organizational forms of their work cannot hinder the further development of local selfgovernment (Shpak, 2013, pp. 58-62; Semko, 2011, p. 55).

The implementation of organizational actions is structured, systematic form of activity of public administrators of local development (proceedings, conferences, sessions, meetings, etc.) determining the internal organization of their functioning for the exercise of the powers, tasks and functions of public administration in the field of administration of local development.

The focus should also be on the performance of logistical operations, which in most cases are auxiliary. They serve functioning of the entire public sector. These operations are aimed at an enabling environment for the performance of administrative functions by the actors concerned. Logistical operations include the preparation of materials for organizational activities, office management, the preparation of certificates, reports, documents, etc. The role and importance of logistical operations 
cannot be underestimated. Administration is highly dependent on them (Kolpakov, 2012, pp. 102-103).

According to V. Halunko, logistic operations determinethe provision by public administration of collection, storage and processing of information, use of technical means, logistical working conditions, etc. They play a auxiliary role in the system of administrative activities of public administrators (Halunko et al., 2018 , p. 138, 143). These include actions that directly make a new legal provision, alter existing legal relations or become a necessary condition for legal effects, whether or not they are intended to do so. Examples of such actions include registration, documentation, taking an oath of office, enforcement of administrative sanctions, enforcement of coercive measures without the prior issuance of such regulations (for example, the use of firearms as a last resort) (Halunko et al., 2018, p. 138; Ivanyshchuk, 2014, p. 47).

Therefore, logistical operations, as forms of activity of public administration of local development in Ukraine, play a statutory role in legalizing legal relations in resolving local issues.

The above actions of public administration of local development are classical forms of their administrative activities, but special forms, such as those of the Ministry of Community and Territorial Development, should also be taken into account and, according to O. Pieshyi, be grouped into: 1) legal (legally significant) forms of activity: law-making (interdepartmental and departmental), law application (certification of legal facts, resolution of legal conflicts and bringing perpetrators to justice), constituent, monitoring and supervising, interpretation activities; 2 ) organizational forms: administrative and economic (logistical support for the Ministry's activities), organizational and prescriptive activities (staffing and operational management of the Ministry); 3) information: public disclosure of the Ministry's activities (press conferences, press releases, information stands, the official website) and responses to citizens' communications and information requests regarding access to public information; 4) communication: communication between the Ministry and other public administration bodies and exchange of information within a unified electronic document flow information system (Pieshyi, 2019). The Ministry of Community and Territorial Development, in carrying out its tasks, cooperates with other State bodies, subsidiary bodies and services established by the President of Ukraine, temporary advisory, consultative and other subsidiary bodies, formed by the Cabinet of Ministers of Ukraine, bodies for local self-government, citizens' associations, public unions, trade unions and employers' organizations, the relevant bodies of foreign States and international organizations, as well as enterprises, institutions, organizations (communication form) (Pieshyi, 2019).

Thus, a scientist O. Pieshyi vividly demonstrates the interrelation of the category of form and method of activity of public administration, which should be considered inseparably (Pieshyi, 2019). The legal literature review reveals that if the form of public administration performance can be rather clearly demonstrated, as well as its legal content and main function, its methods are less legally regulated. However, there are some difficulties in understanding the category of method, with its identifying in contrast with the form of public administration, as well as with the legal regulatory method. The most well-founded view is that methods of public administration are applied by authorised actors of administrative law (public administration), where the form is primary to the method. It shows that specific actions of public administration are carried out through their incorporation, for example, into a legal regulation entailing legal effects. On the contrary, the method enables to see the nature of the relationship between the subject and the object of the influence. It necessarily finds expression in the form of public administration. That is, if there were no form of public administration, the methods of public administration would have been meaningless. For example, how can administrative sanctions be applied or a natural or legal person licensed without documenting such actions, that is, without adopting a legal regulation of public administration? Therefore, the method of public administration is inextricably linked to its forms (Kovalenko, 2012, p. 278; Kuzmenko, 2018, p. 74).

\section{Conclusions}

To sum up the consideration of the issues of local development instruments, the author makes the following conclusions.

The main instrument for public administration of local development in Ukraine is an administrative provision, or more precisely, their totality in a specific regulation, the most recent of which is represented by the legal regulatory framework that logically integrates all the principles, rules and procedures that are essential for the efficiency and effectiveness of a particular public administration. The instrument of implementation of public administration of local development in Ukraine and the instruments of activities of public administration implementing the mechanism for State power and service implementation of public authority in local communities, are different legal phenomena. For example, one of the instruments of public administration of local development in Ukraine is the State 
Strategy for Regional Development (currently approved for 2021-2027 by the Resolution of the Cabinet of Ministers of 5 August 2020 № 695), while the instruments of its implementation are concrete administrative actions of authorized public administrators of local development, such as:

- the issuance of individual administrative regulations as a form of administrative activity of a public administrator of local development is law application of specific individual prescriptions of a public administrator, the legal content thereof is the creation, modification and termination ofinternaladministrativelegalrelations, temporary or definite. The collective issuance of regulatory and individual administrative regulations by the public administrators of local development is the exercise of the will of the public administrator during his or her term of office of a general or specific individual nature, which define specific local development activities, goals and plans related to finance, infrastructure development, involvement of entrepreneurs, investors, business projects, improvement of the quality of services at the local level, addressing other local issues and different needs of the territorial community;

- the administrative contracts are a rather common form of administrative activity of public administrators of local development in Ukraine, which are the concluded between two administrative actors in different forms (agreement, memorandum, protocol) and contain powers in respect of joint legal measures of activity, partnership, solution of obligations in the public-legal field of local development;

- the implementation of organizational actions is structured, systematic forms of activities of public administrators of local development (proceedings, conferences, sessions, meetings, etc.) determining the internal organization of their functioning for the exercise of the powers, tasks and functions of public administration in the field of administration of local development;

- logistical operations, as forms of activity of public administration of local development in Ukraine, play a statutory role in legalizing legal relations in resolving local issues.

Therefore, the administrative instruments for the activities of public administration of local development in Ukraine are the interrelated set of external expressions of the activities of the public administrators (forms) and the ways in which they influence legal relations (methods) in respect of local development administration, which contribute to specific local development actions, goals and strategies, to addressing local issues and to meeting the legitimate needs of society in the democratization process.

\section{References:}

Bila, V. (2020). Pravovi formy publichnoho administruvannia v Ukraini [Legal forms of public administration in Ukraine]. Extended abstract of Doctor's thesis. Kyiv: Natsionalnyi aviatsiinyi universytet [in Ukrainian].

Halunko, V., Dikhtiievskyi, P., Kuzmenko, O., Stetsenko, S. (2018). Administratyone pravo Ukrainy [Administrative law of Ukraine]. Kherson: OLDI-PLIuS [in Ukrainian].

Halunko, V., Kurylo, V., Koroied, S. (2015). Administratyvne pravo Ukrainy [Administrative law of Ukraine]. Kherson: Hrin D.S. [in Ukrainian].

Ivanyshchuk, A. (2014). Administratyvno-pravove rehuliuvannia diialnosti sudovoi hilky vlady: teoriia i praktyka [Administrative and legal regulation of the judiciary: theory and practice]. Kyiv: Universitet "Ukraina" [in Ukrainian].

Kalynovska, T. (2009). Klasyfikatsiia pravovykh aktiv mistsevoho samovriaduvannia [Classification of legal regulations of local self-government]. Pravo Ukrainy - Law of Ukraine, 10, 219-224 [in Ukrainian].

Kaminska, N. (2010). Mistseve samovriaduvannia: teoretyko-istorychnyi i porivnialno-pravovyi analiz [Local self-government: theoretical-historical and comparative-legal analysis]. Kyiv: KNT [in Ukrainian].

Kolpakov, V. (2012). Poniattia form publichnoho administruvannia [The concept of forms of public administration]. Administratyone pravo i protses - Administrative law and process, 2, 89-103 [in Ukrainian].

Kovalenko, A. (1997). Mistseve samovriaduvannia: pryroda, oznaky, mezhi [Local selfgovernment: nature, signs, boundaries]. Pravo Ukrainy - Law of Ukraine, 2, 3-10 [in Ukrainian].

Kovalenko, V. (2012). Kurs administratyonoho prava Ukrainy: pidruchnyk [Course of administrative law of Ukraine]. Kyiv: Yurinkom Inter [in Ukrainian].

Kuzmenko, O. (2018). Kurs administratyonoho prava Ukrainy [Course of administrative law of Ukraine]. Kyiv: Yurinkom Inter [in Ukrainian].

Paterylo, I. (2013). Instytut instrumentiv diialnosti publichnoi administratsii u systemi administratyvnoho prava Ukrainy [Institute of tools of public administration activity in the system of administrative law of Ukraine]. Naukovyi visnyk Dnipropetrovskoho derzhavnoho universytetu vnutrishnikh sprav - Scientific Bulletin of Dnipropetrovsk State University of Internal Affairs, 1, 283-289 [in Ukrainian]. 
Petryshyna, M. (2012). Akty orhaniv i posadovykh osib mistsevoho samovriaduvannia: sutnist ta osoblyvosti [Acts of bodies and officials of local self-government: essence and features]. Visnyk akademii pravooykh nauk Ukrainy - Bulletin of the Academy of Legal Sciences of Ukraine, 1, 66-76 [in Ukrainian].

Pieshyi, O. (2019). Formy diialnosti Ministerstva rozvytku hromad i terytorii [Forms of activity of the Ministry of Development of Communities and Territories]. Prykarpatskyi yurydychnyi visnyk - Prykarpattya Legal Bulletin, 2(27), 42-46 [in Ukrainian].

Semko, S. (2011). Orhanizatsiini formy roboty predstavnytskykh orhaniv mistsevoho samovriaduvannia [Organizational forms of work of representative bodies of local self-government]. Candidate's thesis. Kharkiv: Natsionalna yurydychna akademiia Ukrainy imeni Yaroslava Mudroho [in Ukrainian].

Shpak, Yu. (2013). Poniattia ta vydy orhanizatsiinykh form diialnosti orhaniv mistsevoho samovriaduvannia [Concepts and types of organizational forms of activity of local governments]. Naukovyi visnyk Mizhnarodnoho humanitarnoho universytetu - Scientific Bulletin of the International Humanities University, 5, 58-62 [in Ukrainian].

Starilov, Yu. (2002). Kurs obshchego administrationogo prava [General administrative law course]. Moscow: Norma [in Russian].

Verkhovna Rada of Ukraine (1997). Zakon Ukrainy "Pro mistseve samovriaduvannia v Ukraini" vid 21 travnia 1997 r. № 280/97-BP [Law of Ukraine “On Local Self-Government in Ukraine” from May 21, 1997 № 280/97-BP]. Retrieved from: https://zakon.rada.gov.ua/laws/show/280/97-вp\#Text [in Ukrainian].

\section{Віталій Оксінь,}

доктор юридичних наук, провідний науковий співробітник, Науково-дослідний інститут публічного права, вулиия Г. Кірпи, 2A, Київ, Україна, індекс 03035, 6222410@ukr.net

ORCID: orcid.org/0000-0001-6080-7752

\section{АДМІНІСТРАТИВНИЙ ІНСТРУМЕНТАРІЙ ДІЯЛЬНОСТІ ПУБЛІЧНОЇ АДМІНІСТРАЦЇ̈ У СФЕРІ МІСЦЕВОГО РОЗВИТКУ В УКРАЇНІ}

Анотація. Метою статmi є з'ясування адміністративного інструментарію діяльності публічної адміністрації у сфері місцевого розвитку в Україні.

Результати. У статті досліджено нормативно-правові акти та теоретичні доробки щодо поняття, елементів адміністративного інструментарію діяльності публічної адміністрації у сфері місцевого розвитку України. Визначено, що адміністративний інструментарій діяльності публічної адміністрації у сфері місцевого розвитку представлений класичними формами адміністративної діяльності та специфічними методами іх реалізації. Автором доведено, що основним інструментом публічного адміністрування місцевого розвитку в Україні є адміністративно-правова норма, а точніше, сукупність норм у певному акті. Останні представлені законодавчо-нормативною базою, що логічно об'єднує всі принципи, правила та процедури, дотримання яких є необхідною умовою ефективності й результативності конкретної адміністративної діяльності публічної адміністрації. У роботі зроблено висновок про те, що інструмент реалізації публічного адміністрування місцевого розвитку в Україні та інструменти діяльності публічної адміністрації, яка реалізовує механізм утілення державно-владної та сервісної реалізації публічної влади на місцях, $€$ різними правовими явищами, а інструментами їі реалізації слугують конкретні адміністративні дії уповноважених суб’єктів публічної адміністрації місцевого рівня.

Висновки. Таким чином, адміністративні інструменти діяльності публічної адміністрації у сфері місцевого розвитку в Україні - це взаємозалежна сукупність зовнішнього вираження діяльності суб'єктів публічної адміністрації (форм) і способів їх впливу на правовідносини (методів) щодо адміністрування місцевого розвитку, завдяки яким реалізуються конкретні заходи, цілі та стратегії місцевого розвитку, розв'язуються питання місцевого значення та задовольняються законні потреби громади у процесі демократизаціі.

Ключові слова: адміністративно-правовий інструментарій, місцевий розвиток, публічна адміністрація, діяльність, форми, методи, адміністративно-правова норма.

The article was submitted 15.11.2021

The article was revised 06.12.2021

The article was accepted 27.12.2021 